\section{Halosulfuron Tank Mixtures and Adjuvants for Weed Control in Pumpkin Production}

\author{
Katie J. Kammler, S. Alan Walters ${ }^{1}$, and Bryan G. Young \\ Department of Plant, Soil, and Agricultural Systems, Southern Illinois \\ University, 1205 Lincoln Drive, Room 176 Agricultural Building, \\ Carbondale, IL 62901-4415
}

Additional index words. clethodim, crabgrass, Cucurbita pepo, Digitaria spp., herbicide interactions, postemergence herbicides, sethoxydim

\begin{abstract}
Field studies were conducted to evaluate postemergence combinations of halosulfuron plus sethoxydim or clethodim with various adjuvants for effects on jacko-lantern pumpkin (Cucurbita pepo L.) injury and yields and control of large [Digitaria sanguinalis (L.) Scop.] and smooth crabgrass [D. ischaemum (Schreb. ex Schweig.) Schreb. ex Muhl.]. Halosulfuron caused $27 \%$ and $14 \%$ pumpkin injury at $28 \mathrm{~d}$ after postemergence treatment (DAPT) in 2004 and 2005, respectively. Tank-mixing sethoxydim or clethodim with halosulfuron did not increase pumpkin injury compared with halosulfuron alone. Pumpkin injury from sethoxydim and clethodim alone at 28 DAPT ranged from $19 \%$ to $23 \%$ in 2004 , but was only $7 \%$ to $8 \%$ in 2005 . The addition of oilbased adjuvants to halosulfuron did not affect pumpkin injury compared with using a nonionic surfactant (NIS). The tank mixture of halosulfuron and sethoxydim did not affect crabgrass control regardless of adjuvant. However, the addition of halosulfuron to clethodim plus NIS reduced control of crabgrass from $89 \%$ to $77 \%$ at 28 DAPT. Crabgrass control was unaffected by the addition of halosulfuron to clethodim with crop oil concentrate (COC) or a NIS/COC blend. None of the herbicide treatments provided pumpkin yield (fruit no./ha) similar to the weed-free control. The pumpkin yield of treatments using postemergence herbicides was at least $50 \%$ less than the weed-free treatment. These low pumpkin yields were most likely the result of the combination of pumpkin injury from the herbicide applications and insufficient weed control.
\end{abstract}

Weed control is a major issue in jack-olantern pumpkin production as a result of the limited number of registered herbicides (Walters et al., 2008). Many of the herbicides currently registered for pumpkins have potential crop injury risks, high costs, and/ or insufficient weed control (Brown and Masiunas, 2002). Herbicides registered for use in midwest U.S. pumpkin production include bensulide, carfentrazone-ethyl, clethodim, clomazone, ethalfluralin, halosulfuron, naptalam, sethoxydim, and trifluralin (Egel et al., 2008). Clomazone is one of the most widely used pumpkin herbicides but does not adequately control many weeds, including pigweed (Amarathus spp.) and nightshade (Solanum spp.). Clomazone may also result in pumpkin injury and has the potential to injure other agronomic or horticultural crops that might be rotated into the field the next year (Brown and Masiunas, 2002). The combination of clomazone and ethalfluralin is considered the standard herbicide treatment for weed control in jacko-lantern pumpkins despite the injury that frequently occurs from clomazone (Brown and Masiunas, 2002). Halosulfuron is currently registered for pre-emergence (PRE) and postemergence (POST) broadleaf weed

\footnotetext{
Received for publication 10 Apr. 2008. Accepted for publication 7 June 2008.

${ }^{1}$ To whom reprint requests should be addressed; e-mail awalters@siu.edu
}

control in jack-o-lantern pumpkins (Egel et al., 2005), although stunting and chlorosis injury is often observed on pumpkin plants. Halosulfuron has also been shown to injure squash (Cucurbita pepo L.), especially when applied POST. Although squash plants begin to recover from the stunting and chlorosis caused by halosulfuron applied POST at 3 to 4 weeks after application, plant height and shoot biomass were reduced (Webster et al., 2003). Pre-emergence applications of halosulfuron also provide significant injury to squash (Walters et al., 2005). However, Umeda (1998) found halosulfuron applied PRE in pumpkins provided less crop injury compared with POST applications. injury to pumpkins when applied PRE, POST herbicide applications are often necessary as a result of insufficient pre-emergent weed control and/or late-season weed emergence. Unfortunately, halosulfuron does not control grasses (Buker et al., 1998); therefore, tank mixtures of POST graminicide herbicides may be necessary to achieve optimal weed control in pumpkins. Herbicide combinations may increase the spectrum of weed control and decrease production costs by reducing the number of applications (Hatzios and Penner, 1985).

Tank mixtures of broadleaf (halosulfuron) and grass (sethoxydim and clethodim) herbicides may provide better weed control compared with current weed management
Although halosulfuron provides less programs in pumpkins. Halosulfuron inhibits acetolactate syntase (ALS) and sethoxydim and clethodim inhibit the acetyl CoA carboxylase (ACCase) enzyme (Senseman, 2007). Antagonism has been documented between these two modes of action when tank-mixed with reduced grass control resulting when sethoxydim was tank-mixed with primisulfuron, an ALS-inhibiting herbicide (Young et al., 1996). Adjuvants can be used to overcome an antagonism between herbicides (Campbell and Penner, 1982). For example, the antagonism of sethoxydim and the sodium salt of bentazon was overcome by the addition of ammonium sulfate and changing the adjuvant from a crop oil concentrate (COC) to a high-concentrate, oil-based adjuvant (Jordan et al., 1989).

A nonionic surfactant (NIS) is recommended for use with halosulfuron because the label states that the use of a COC will result in increased crop injury and should not be used for POST applications (Gowan Company, 2008). However, sethoxydim and clethodim require the use of a COC or seed oil to achieve maximum efficacy (BASF Corporation, 2006; Valent U.S.A. Corporation, 2007). Therefore, the objective of this research was to determine the adjuvant(s) to use with tank mixtures of halosulfuron and sethoxydim or clethodim to achieve optimal weed control while minimizing pumpkin crop injury

\section{Materials and Methods}

Research was conducted at a field site infested with crabgrass weed species in 2004 and 2005 at Southern Illinois University Horticulture Research Center in Carbondale, IL. The field soil was a Hosmer silt loam with a $1.5 \%$ organic matter content and a $\mathrm{pH}$ of 6.5. The soil was tilled before seeding. The plots were $1.2 \mathrm{~m}$ wide by $6.1 \mathrm{~m}$ long. 'Howdy Doody' jack-o-lantern pumpkin seed was planted 16 June each year with one row per plot and at in-row plant spacings of $1.2 \mathrm{~m}$ allowing five plants per plot.

The experiment had 18 treatments and was set up in a randomized complete block with four replications. Herbicide treatments included: halosulfuron (35 g.ha ${ }^{-1}$ a.i.), sethoxydim (53 g.ha ${ }^{-1}$ a.i.), clethodim (26 g.ha ${ }^{-1}$ a.i. $)$, halosulfuron + sethoxydim $(35+$ $53 \mathrm{~g} \cdot \mathrm{ha}^{-1}$ a.i.), and halosulfuron + clethodim $\left(35+26 \mathrm{~g} \cdot \mathrm{ha}^{-1}\right.$ a.i. $)$. Each herbicide/herbicide combination was applied with three different adjuvants: 1) NIS (0.25\% v/v), 2) COC (1\% $\mathrm{v} / \mathrm{v})$, and 3) NIS/COC (40/60; $0.5 \% \mathrm{v} / \mathrm{v})$. Additional treatments included a standard treatment consisting of clomazone plus ethalfluralin $\left(350+1121 \mathrm{~g} \cdot \mathrm{ha}^{-1}\right.$ a.i.) PRE followed by halosulfuron (35 g.ha ${ }^{-1}$ a.i.) with NIS POST, a nontreated, and a weed-free (handweeded) control. These additional treatments were included primarily for relative comparisons in pumpkin yields. The clomazone plus ethalfluralin PRE treatment was applied the same day as pumpkin planting and the other herbicide/adjuvant combinations were applied $21 \mathrm{~d}$ after planting when pumpkin plants had two to three true leaves and the 
weed species were $\approx 10$ to $15 \mathrm{~cm}$ tall. Herbicide treatments were applied with a $\mathrm{CO}_{2}$ pressurized backpack sprayer using 8003 flatfan spray tips at $275 \mathrm{kPa}$ in $187 \mathrm{~L} \cdot \mathrm{ha}^{-1}$ water. Overhead sprinkler irrigation was used to activate the PRE herbicides and to ensure that the plants received at least $2.5 \mathrm{~cm}$ water weekly throughout the growing season.

Standard cultural practices for pumpkins in Illinois were used (Egel et al., 2005). After pumpkin seedling emergence, a dry fertilizer was broadcast at rates of $34 \mathrm{~kg} \cdot \mathrm{ha}^{-1}$ nitrogen (N), $40 \mathrm{~kg} \cdot \mathrm{ha}^{-1}$ phosphorus, and $74 \mathrm{~kg} \cdot \mathrm{ha}^{-1}$ potassium. Plots were fertilized again 4 weeks later with $45 \mathrm{~kg} \cdot \mathrm{ha}^{-1} \mathrm{~N}$. Diseases and insects were controlled by spraying recommended rates of esfenvalerate and chlorothalonil every $10 \mathrm{~d}$ for the duration of the experiment. Once flowering commenced, a honeybee (Apis mellifera L.) colony was placed in the field adjacent to the research site to optimize fruit set.

Pumpkin plants were visually rated for discoloration, growth reduction, and overall injury on a scale of $0 \%$ (no discoloration, growth reduction, or injury) to $100 \%$ (complete death) at 7, 14, and $28 \mathrm{~d}$ after postemergence treatment (DAPT). Although the study focused on crabgrass, other species, including giant foxtail (Setaria faberi Herrm.), redroot pigweed (Amaranthus retroflexus L.), and stinkgrass [Eragrostis cilianensis (All.) Vign. ex Janchen], were detected at low densities compared with large and smooth crabgrass. Crabgrass species control was visually evaluated on a scale of $0 \%$ (no control) to $100 \%$ (complete control) at 14 and 28 DAPT and at pumpkin harvest. Weeds were harvested from each plot in a $0.1-\mathrm{m}^{2}$ area, dried at $77^{\circ} \mathrm{C}$ for $48 \mathrm{~h}$, and dry weights were then determined. Pumpkins were harvested twice each year when fruit were orange in color with marketable and cull fruit weights determined for each plot.

The primary objective of this research was to identify any interaction of halosulfuron tank mixtures and adjuvants for crop injury and weed control. Thus, analysis of variance (ANOVA) was performed to determine the significance of the main effects and interaction of herbicide tank mixtures with adjuvants for the crop injury and weed control data. In addition, weed control (\%) and pumpkin plant injury data (\%) were arcsine-transformed before ANOVA; nontransformed means are presented because the arcsine transformation did not alter the interpretation of the data. Data are presented by year when year $\times$ treatment interactions $(P \leq 0.05)$ were detected. Means were separated using Fisher's protected least significant difference $(P \leq 0.05)$.

An economic analysis was conducted based on the economic return on investment (EROI) defined as the gross return minus the treatment cost (Nolte and Young, 2002). Gross return of the treatment was based on an average price of $\$ 1$ per marketable pumpkin (greater than $3 \mathrm{~kg}$ in size) multiplied by the yield benefit of the treatment. The cost of treatment was based on 2006 nondiscounted price of herbicides and adjuvants. The following equation was used to determine EROI for each replication:

$$
\begin{aligned}
\text { EROI }= & {[(\text { treated yield })-(\text { nontreated yield })] } \\
& \times(\$ / \text { pumpkin })-\text { cost of treatment. }
\end{aligned}
$$

\section{Results and Discussion}

Pumpkin plant injury. Overall pumpkin plant injury is presented as a combination of discoloration and growth reduction. Although adjuvant $\times$ year interactions $(P \leq$ $0.05)$ were observed for pumpkin plant injury, no differences $(P>0.05)$ were detected between adjuvants. Therefore, pumpkin plant injury data were pooled over adjuvant and split $\times$ year (Table 1$)$. The year interactions for pumpkin plant injury resulted from more halosulfuron injury relative to the grass herbicides applied alone in 2005 compared with 2004.

Pumpkin injury was $14 \%$ to $19 \%$ at 7 DAPT in 2004 with no differences observed among herbicide treatments (Table 1). At 14 DAPT, pumpkin injury was $30 \%, 22 \%$, and $22 \%$ from halosulfuron, clethodim, and sethoxydim applied alone, respectively. Tankmixing clethodim or sethoxydim with halosulfuron did not increase pumpkin plant injury compared with clethodim and sethoxydim alone. Similar results were observed at 28 DAPT.

Overall pumpkin injury was greatest at 7 DAPT in 2005 with $19 \%$ to $24 \%$ injury from treatments that included halosulfuron and $13 \%$ and $16 \%$ injury from sethoxydim and clethodima applied alone (Table 1). In contrast to 2004, combinations of halosulfuron with either sethoxydim or clethodim increased pumpkin plant injury at 14 and 28
DAPT in 2005 compared with sethoxydim or clethodim applied alone. At 14 DAPT, sethoxydim tank-mixed with halosulfuron increased pumpkin injury by $6 \%$ compared with halosulfuron alone. By 28 DAPT, pumpkin injury was $8 \%$ or less from sethoxydim and clethodim alone and $14 \%$ to $20 \%$ from treatments that included halosulfuron.

Crabgrass species control. No year interactions with treatment or adjuvant were detected $(P>0.05)$ for visual control of large and smooth crabgrass, although adjuvant main effects were significant $(P \leq 0.05)$. Halosulfuron alone provided no control of large or smooth crabgrass (Table 2). Control of large and smooth crabgrass with sethoxydim applied alone was greater with $\mathrm{COC}$ and NIS/COC compared with NIS, which is consistent with label recommendations (BASF Corporation, 2007). The efficacy of clethodim for crabgrass control was not dependent on adjuvant. Tank-mixing halosulfuron with sethoxydim, regardless of adjuvant, did not reduce crabgrass species control compared with sethoxydim applied alone. However, when halosulfuron was tank-mixed with clethodim plus NIS, crabgrass control was reduced from $89 \%$ to $77 \%$. No reduction in crabgrass control occurred with the tank mixture of halosulfuron plus clethodim and $\mathrm{COC}$ or NIS/COC as the adjuvant.

Although adjuvants influenced visual crabgrass control, weed biomass was unaffected by adjuvant. Clethodim and sethoxydim alone reduced crabgrass biomass more than any other treatment (Table 3). Tankmixing halosulfuron with either clethodim or sethoxydim increased Digitaria spp. biomass compared with clethodim and sethoxydim applied alone. In 2004, only sethoxydim and clethodim alone and halosulfuron plus clethodim reduced crabgrass biomass compared with halosulfuron alone. Clethodim and sethoxydim alone and combinations with halosulfuron reduced crabgrass biomass in 2005. However, crabgrass biomass was reduced to a greater extent by the grass herbicides applied alone compared with tank mixtures with halosulfuron. This antagonism between ALS and ACCase-inhibiting herbicides that reduces grass weed control has been documented previously (Holshouser and Coble, 1990; Young et al., 1996).

Pumpkin yield. Pumpkin yield was pooled over years and adjuvants, because no year $x$

\begin{tabular}{|c|c|c|c|c|c|c|}
\hline \multirow[b]{3}{*}{ Herbicide $^{\mathrm{y}}$} & \multicolumn{6}{|c|}{ Pumpkin injury $^{2}$} \\
\hline & \multicolumn{3}{|c|}{2004} & \multicolumn{3}{|c|}{2005} \\
\hline & (2) & 2. & - & & & - \\
\hline Sethoxydim & $14 \mathrm{a}$ & $22 \mathrm{~b}$ & $19 \mathrm{~b}$ & $13 \mathrm{c}$ & $7 \mathrm{c}$ & $8 \mathrm{~b}$ \\
\hline Halosulfuron + sethoxydim & $19 \mathrm{a}$ & $28 \mathrm{ab}$ & $23 \mathrm{ab}$ & $24 \mathrm{a}$ & $20 \mathrm{a}$ & $20 \mathrm{a}$ \\
\hline Clethodim & $17 \mathrm{a}$ & $22 \mathrm{~b}$ & $23 \mathrm{ab}$ & $16 \mathrm{bc}$ & $5 \mathrm{c}$ & $7 \mathrm{~b}$ \\
\hline Halosulfuron + clethodim & $16 \mathrm{a}$ & $28 \mathrm{ab}$ & $21 \mathrm{ab}$ & $23 \mathrm{a}$ & $18 \mathrm{ab}$ & $16 \mathrm{a}$ \\
\hline
\end{tabular}

Table 1. 'Howdy Doody' pumpkin injury from postemergence applications of halosulfuron, sethoxydim, and clethodim in 2004 and 2005.

${ }^{2}$ Pumpkin plants were visually rated for discoloration, growth reduction, and overall injury on a scale of $0 \%$ (no discoloration, growth reduction, or injury) to $100 \%$ (complete death). Means within a column followed by the same letter do not differ significantly according to Fisher's protected least significant difference at $P \leq 0.05$.

${ }^{y}$ Herbicide rates (on a.i. basis) were: halosulfuron at $35 \mathrm{~g} \cdot \mathrm{ha}^{-1}$ a.i., sethoxydim at $53 \mathrm{~g} \cdot \mathrm{ha}^{-1}$ a.i., and clethodim at $26 \mathrm{~g} \cdot \mathrm{ha}^{-1}$ a.i. $\mathrm{DAPT}=$ days after postemergence herbicide treatment. 
Table 2. Influence of adjuvant on control of crabgrass species (Digitaria spp.) from tank mixtures with halosulfuron, sethoxydim, and clethodim at $28 \mathrm{~d}$ after treatment.

\begin{tabular}{|c|c|c|c|}
\hline \multirow[b]{3}{*}{ Herbicide $^{y}$} & \multicolumn{3}{|c|}{ Crabgrass species control $^{z}$} \\
\hline & NIS $^{x}$ & $\mathrm{COC}$ & $\mathrm{NIS} / \mathrm{COC}$ \\
\hline & ------- & $----\%$ & ------------ \\
\hline Halosulfuron & $0 \mathrm{e}$ & $0 \mathrm{e}$ & $0 \mathrm{e}$ \\
\hline Sethoxydim & $79 \mathrm{~cd}$ & $89 \mathrm{ab}$ & $88 \mathrm{a}-\mathrm{c}$ \\
\hline Halosulfuron + sethoxydim & $76 \mathrm{~d}$ & $85 \mathrm{a}-\mathrm{d}$ & $82 \mathrm{~b}-\mathrm{d}$ \\
\hline Clethodim & $89 \mathrm{ab}$ & $92 \mathrm{a}$ & $91 \mathrm{ab}$ \\
\hline Halosulfuron + clethodim & $77 \mathrm{~d}$ & $89 \mathrm{ab}$ & $89 \mathrm{ab}$ \\
\hline
\end{tabular}

${ }^{\mathrm{z}}$ Crabgrass species included large [Digitaria sanguinalis (L.) Scop.] and smooth crabgrass [D. ischaemum (Schreb.) Schreb. ex Muhl.]. Means within or across columns followed by the same letter do not differ significantly according to Fisher's protected least significant difference at $P \leq 0.05$.

${ }^{\mathrm{y}}$ Herbicide rates (on a.i. basis) were: halosulfuron at $35 \mathrm{~g} \cdot \mathrm{ha}^{-1}$ a.i., sethoxydim at $53 \mathrm{~g} \cdot \mathrm{ha} \mathrm{e}^{-1}$ a.i., and clethodim at $26 \mathrm{~g} \cdot \mathrm{ha}^{-1}$ a.i.

${ }^{\mathrm{x}} \mathrm{NIS}$ is nonionic surfactant, COC is crop oil concentrate, and NIS/COC is a blend of nonionic surfactant and crop oil concentrate.

Table 3. Biomass of crabgrass species (Digitaria spp.) as influenced by postemergence applications of halosulfuron tank-mixed with sethoxydim or clethodim in 2004 and 2005

\begin{tabular}{lcr}
\hline & \multicolumn{2}{c}{ Dry wt $\left(\mathrm{g} \cdot \mathrm{m}^{-2}\right)^{\mathrm{z}}$} \\
\cline { 2 - 3 } Treatment $^{\mathrm{y}}$ & \multicolumn{1}{c}{2004} & 2005 \\
\hline Halosulfuron & $1001 \mathrm{a}$ & $922 \mathrm{a}$ \\
Sethoxydim & $193 \mathrm{~d}$ & $0 \mathrm{~d}$ \\
Halosulfuron + sethoxydim & $687 \mathrm{ab}$ & $259 \mathrm{c}$ \\
Clethodim & $251 \mathrm{~cd}$ & $0 \mathrm{~d}$ \\
Halosulfuron + clethodim & $543 \mathrm{bc}$ & $171 \mathrm{c}$
\end{tabular}

${ }^{\mathrm{z}}$ Crabgrass species included in dry weight were: large [Digitaria sanguinalis (L.) Scop.] and smooth crabgrass [D. ischaemum (Schreb.) Schreb. ex Muhl.]. Means within a column followed by the same letter do not differ significantly according to Fisher's protected least significant difference at $P \leq 0.05$.

${ }^{\mathrm{y}}$ Herbicide rates (on a.i. basis) were: halosulfuron at $35 \mathrm{~g} \cdot \mathrm{ha}^{-1}$ a.i., sethoxydim at $53 \mathrm{~g} \cdot \mathrm{ha}^{-1}$ a.i., and clethodim at $26 \mathrm{~g} \cdot \mathrm{ha}^{-1} \mathrm{a} . \mathrm{i}$

adjuvant or treatment interactions were detected and adjuvants did not differ $(P>$ $0.05)$. Although the greatest pumpkin yields (fruit no./ha) were obtained in the weed-free control, the standard treatment of clomazone plus ethalfluralin PRE followed by halosulfuron + NIS POST provided greater pumpkin yields compared with most other herbicide combinations (Table 4). The use of clethodim or sethoxydim alone, tank mixtures of clethodim or sethoxydim with halosulfuron, and the nontreated control produced similar low pumpkin yields, which were $\approx 50 \%$ to $70 \%$ less than the weed-free control.

Economic return on investment. Pumpkin EROI was pooled over years and adjuvants, because no year interactions with adjuvant or treatment were detected and adjuvants did not differ $(P>0.05)$. Pumpkin EROI indicated similar trends as the yield data. The standard treatment (clomazone plus ethalfluralin PRE followed by halosulfuron + NIS POST) returned $\$ 1449 /$ ha, whereas halosulfuron plus sethoxydim provided a return of $\$ 560 /$ ha (Table 4). All other treatments provided negative returns as a result of low yields and the cost of the herbicides. The treatments with the highest yields provided the greatest EROIs regardless of herbicide costs.

Combinations of halosulfuron with either clethodim or sethoxydim produced greater
Table 4. 'Howdy Doody' pumpkin yield and economic return on investment (EROI) as influenced by postemergence applications of halosulfuron tank-mixed with sethoxydim and clethodim.

\begin{tabular}{lcc}
\hline & $\begin{array}{c}\text { Marketable } \\
\text { fruit }^{\mathrm{z}} \\
\text { no./ha }\end{array}$ & $\begin{array}{c}\text { EROI }^{\mathrm{y}} \\
\text { \$/ha }\end{array}$ \\
\hline Treatment & $7,318 \mathrm{a}$ & $-\overline{\mathrm{w}}^{\mathrm{w}}$ \\
Weed-free & $4,425 \mathrm{~b}$ & $1,449 \mathrm{a}$ \\
Standard & $3,403 \mathrm{bc}$ & $560 \mathrm{ab}$ \\
Halosulfuron + sethoxydim & $2,608 \mathrm{~cd}$ & $-145 \mathrm{bc}$ \\
Sethoxydim & $2,440 \mathrm{~cd}$ & $-400 \mathrm{bc}$ \\
Halosulfuron + clethodim & $2,383 \mathrm{~cd}$ & $-367 \mathrm{bc}$ \\
Clethodim & $1,250 \mathrm{~d}$ & $-1,568 \mathrm{c}$ \\
\hline Halosulfuron &
\end{tabular}

${ }^{\mathrm{z}}$ Marketable fruit were those greater than $3 \mathrm{~kg}$ in size. Means within a column followed by the same letter do not differ significantly according to Fisher's protected least significant difference at $P \leq 0.05$.

${ }^{y}$ EROI was calculated as [(treated no./ha) (nontreated no./ha) $] \times(\$ 1 /$ pumpkin $)-$ cost of herbicide treatment. The cost of a treatment was based on 2006 nondiscounted price of herbicides and adjuvants.

xHerbicide rates (on a.i. basis) were: halosulfuron at $35 \mathrm{~g} \cdot \mathrm{ha}^{-1}$ a.i., sethoxydim at $53 \mathrm{~g} \cdot \mathrm{ha}^{-1}$ a.i., and clethodim at $26 \mathrm{~g} \cdot \mathrm{ha}^{-1}$ a.i.. The standard treatment was clomazone + ethalfluralin pre-emergence followed by halosulfuron postemergence.

${ }^{w}$ Weed-free EROI not calculated as no-herbicide treatment costs.

pumpkin plant injury and reduced weed control, which most likely suppressed pumpkin fruit yield. Furthermore, the combination of halosulfuron with either clethodim or sethoxydim produced approximately the same yields regardless of adjuvant. Rapp et al. (2004) indicated that greater yield losses in pumpkin production can be attributed more to weed competition than to herbicide injury, which was also probably the case in our study. Currently, growers must sustain some pumpkin yield reductions as a result of lack of sufficient herbicides available for weed control, because handweeding is not economical. An optimal mixture of herbicides should result in less crop injury but should have an additive or synergistic effect on weed control (Hatzios and Penner, 1985); therefore, continued research is essential to determine options having broader spectrums of weed control in pumpkin with less yield reductions. The ideal situation is to use only one postemergence herbicide application, which would allow for reduced labor, fuel, and equipment costs and would ultimately provide more profit for the grower. Therefore, improvements in pumpkin weed management are still necessary for growers to realize maximum yields.

\section{Literature Cited}

BASF Corporation. 2006. Poast herbicide label. 13 Mar. 2008. <http://www.greenbook.net/docs/ LABEL/L26409.PDF>.

Brown, D. and J. Masiunas. 2002. Evaluation of herbicides for pumpkin (Cucurbita spp.). Weed Technol. 16:282-292.

Buker, R.S., W.M. Stall, and S.M. Olson. 1998. Watermelon tolerance to halosulfuron applied preemergence and postemergence. Proc. Annu. Meet. Fla. State. Hort. Soc. 110:323-325.

Campbell, J.R. and D. Penner. 1982. Compatibility of diclofop and BAS 9052 with bentazon. Weed Sci. 30:458-462.

Egel, D., R. Foster, E. Maynard, R. Weinzierl, M. Badadoost, H. Taber, R. Bauernfeind, T. Carey, M. Kennelly, B. Hutchinson, and B. Barrett. 2008. Midwest vegetable production guide for commercial growers 2008. University of Illinois Extension Bulletin C1373-08.

Egel, D., F. Lam, E. Maynard, R. Weinzierl, M. Badadoost, H. Taber, B. Hutchinson, and L. Jett. 2005. Midwest vegetable production guide for commercial growers 2005. University of Illinois Extension Bulletin C1373-05.

Gowan Company. 2008. Sandea herbicide label. 15 Mar. 2008. <http://www.gowanco.com/Reference/Document.aspx?rid=422>.

Hatzios, K.K. and D. Penner. 1985. Interactions of herbicides with other agrochemicals in higher plants. Rev. Weed Sci. 1:1-63.

Holshouser, D.L. and H.D. Coble. 1990. Compatibility of sethoxydim with five postemergence broadleaf herbicides. Weed Technol. 4:128-133.

Jordan, D.L., A.C. York, and R.J. Corbin. 1989. Effect of ammonium sulfate and bentazon on sethoxydim absorption. Weed Technol. 4:128-133.

Nolte, S.A. and B.G. Young. 2002. Efficacy and economic return on investment for conventional and herbicide resistant corn (Zea mays). Weed Technol. 16:371-378.

Rapp, H.S., R.R. Bellinder, H.C. Wien, and F.M Vermeylen. 2004. Reduced tillage, rye residues, and herbicides influence weed suppression and yield of pumpkins. Weed Technol. 18:953-961.

Senseman, S.A. 2007. Herbicide handbook. 9th ed. Weed Science Society of America Lawrence, KS.

Umeda, K. 1998. Weed control in melons using preemergence and postemergence herbicides. Proc.West. Soc. Weed Sci. 51:74.

Valent U.S.A. Corporation. 2007. Select herbicide label. 15 Mar. 2008. <http://www.cppress.com/ docs/LABEL/L3829.PDF>.

Walters, S.A., S.A. Nolte, and B.G. Young. 2005. Influence of winter rye and preemergence herbicides on weed control in no-tillage zucchini squash production. HortTechnology $15: 238-243$.

Walters, S.A., B.G. Young, and R.F. Krausz. 2008. Influence of tillage, cover crop, and pre-emergence herbicides on weed control and pumpkin yield. Intl. J. Veg. Sci. 14(2):148-161.

Webster, T.M., A.S. Culpepper, and W.C. Johnson III 2003. Response of squash and cucumber cultivars to halosulfuron. Weed Technol. 17:173-176.

Young, B.G., S.E. Hart, and L.M. Wax. 1996 Interactions of sethoxydim and corn (Zea mays) postemergence broadleaf herbicides on three annual grasses. Weed Technol. 10:914-922. 